\title{
A Semianalytical Model Using MODIS Data to Estimate Cell Density of Red Tide Algae (Aureococcus anophagefferens)
}

\author{
Lingling Jiang, ${ }^{1}$ Lin Wang, ${ }^{2}$ Xinyu Zhang, ${ }^{3}$ Yanlong Chen, ${ }^{2}$ and Deqi Xiong ${ }^{1}$ \\ ${ }^{1}$ College of Environmental Science and Engineering, Dalian Maritime University, No. 1 Linghai Road, Dalian 116026, China \\ ${ }^{2}$ National Marine Environmental Monitoring Center, No. 42 Linghe Road, Dalian 116023, China \\ ${ }^{3}$ Navigation College, Dalian Maritime University, No. 1 Linghai Road, Dalian 116026, China \\ Correspondence should be addressed to Lingling Jiang; j115@163.com
}

Received 21 April 2015; Accepted 8 July 2015

Academic Editor: Xiaofeng Li

Copyright (C) 2016 Lingling Jiang et al. This is an open access article distributed under the Creative Commons Attribution License, which permits unrestricted use, distribution, and reproduction in any medium, provided the original work is properly cited.

\begin{abstract}
A multiband and a single-band semianalytical model were developed to predict algae cell density distribution. The models were based on cell density $(N)$ dependent parameterizations of the spectral backscattering coefficients, $b_{b}(\lambda)$, obtained from in situ measurements. There was a strong relationship between $b_{b}(\lambda)$ and $N$, with a minimum regression coefficient of 0.97 at $488 \mathrm{~nm}$ and a maximum value of 0.98 at other bands. The cell density calculated by the multiband inversion model was similar to the field measurements of the coastal waters (the average relative error was only $8.9 \%$ ), but it could not accurately discern the red tide from mixed pixels, and this led to overestimation of the area affected by the red tide. While the single-band inversion model is less precise than the former model in the high chlorophyll water, it could eliminate the impact of the suspended sediments and make more accurate estimates of the red tide area. We concluded that the two models both have advantages and disadvantages; these methods lay the foundation for developing a remote sensing forecasting system for red tides.
\end{abstract}

\section{Introduction}

Red tides are always observed in coastal waters all over the world. They not only harm marine fisheries and aquaculture, deteriorate the marine environment, and affect the coastal tourist industry, but also cause human health problems $[1,2]$. Monitoring the blooms and forecasting their development and movement are an important prerequisite for mitigating the impacts of such harmful algal blooms. Remote sensing has become an effective means of regularly monitoring algae blooms due to their synoptic and repetitive satellite coverage [3-8].

Most present efforts to detect and monitor red tides are based on chlorophyll a concentrations [9-14]. And the algorithms mainly include blue-to-green ratio algorithms and sensitivity of fluorescence algorithms [15-17]. The blueto-green ratio algorithm was designed according to algal spectral properties in visible bands. It provides reasonable estimates of chlorophyll concentrations in Case I Water, in which chlorophyll is the optically dominant constituent [18].
However, the algorithm is not robust in Case II Water, in which colored dissolved organic matter (CDOM) and/or suspended sediment are present. These constituents increase the absorption of blue bands and influence the spectral ratio of reflectance [19-22], resulting in erroneously high estimates of chlorophyll concentrations and misidentifying the sample as red tide water $[13,23,24]$. To reduce the error arising from the influence of CDOM, the chlorophyll fluorescent method was based on positive correlation between fluorescence line height (FLH) and chlorophyll concentrations. This became the new standard of measuring chlorophyll concentrations in Case II Water. The FLH measurements were estimated using band triplets included in Medium Resolution Imaging Spectrometer (MERIS) and Moderate Resolution Imaging Spectrometer (MODIS) sensors. The method was widely used by researchers $[12,25,26]$, who have found that fluorescence was useful for separating true pigment concentrations from the strong influence of CDOM effects. However, the MODIS FLH approach uses a simple radiance peak of $678 \mathrm{~nm}$ compared with the bottom line of 667 and $748 \mathrm{~nm}$ and is less sensitive to 
high concentrations of suspended sediment due to increasing interactions between chlorophyll and the sediment [13, 27]. Otherwise, the relationship between FLH and chlorophyll concentration is not consistent for the different red tide alga and a negative correlation was found among some algae [28]. Thus, identification of blooms remains out of reach with these data. Recently, some approaches have been developed to monitor red tides based on optical closure relationships, such as using semianalytical and model-based approaches to measure apparent optical properties (AOPs) and the relevant inherent optical properties (IOPs) of seawater [29-31]. The cell density of a specific alga is the primary factor used to discern red tides in field monitoring and this value is determined by cell size. The pigment type and proportional size vary between algae species and so chlorophyll concentrations cannot be used to correctly identify red tides.

Algal spectral backscattering provides useful information because it is a function of algae size and refractive indices. Under normal conditions, oceanic particle size distributions appear dispersed; however, a distinctive feature of blooms is a high concentration of less dispersed distribution cells (with uniform cell diameters) that have unique backscattering spectra and might drastically alter ocean color. Thus, we used the available cell density information for a continuous and systematic study of algal blooms. We tested a combined analysis that uses simple spectral properties and band ratio to detect algal blooms with high accuracy using MODIS spectral data. The purpose of this study was to (1) identify the spectral characteristics of red tides (specifically Aureococcus anophagefferens blooms) based on backscattering coefficients, radiance, and cell density; (2) build a cell density remote sensing inversion model according to the MODIS data; (3) map areas of red tide by using the model; and (4) validate the new model using in situ data and addressing sources of error that limit the potential utility of satellite ocean color data for predicting red tides.

\section{Formulation of the Reflectance Model}

Remote sensing of ocean color relies on detecting the light signal that leaves the water surface and reaches a sensor on board a satellite. Ocean remote sensing reflectance, $R_{\mathrm{rs}}$, is defined as the ratio of water-leaving radiance to downwelling irradiance, measured just above the sea surface, and it is dependent on the backscattering and absorption properties of seawater and the angular distribution of light within the ocean. Using radiative transfer theory, $R_{\mathrm{rs}}$ can be expressed as follows $[32,33]$ :

$$
R_{\mathrm{rs}}\left(\lambda, 0^{+}\right)=\frac{t^{2}}{n^{2}} \frac{f}{Q(\lambda)} \frac{b_{b}(\lambda)}{a(\lambda)+b_{b}(\lambda)},
$$

where $b_{b}(\lambda)$ is the total backscattering coefficient; $a(\lambda)$ is the total absorption coefficient of the seawater; $t$ is the transmittance across the air-sea interface; $n$ is the index of refraction of seawater; $f$ is an empirical factor that is a function of the solar zenith angle; and $Q(\lambda)$ is the ratio of upwelling irradiance to upwelling radiance, $Q(\lambda)=E_{u}(\lambda) / L_{u}(\lambda)[34]$.
By making approximations for these latter terms [35], $R_{\mathrm{rs}}(\lambda)$ can be related to the subsurface remote sensing reflectance, $r_{\mathrm{rs}}(\lambda)$, as follows:

$$
R_{\mathrm{rs}}(\lambda)=\frac{0.5 r_{\mathrm{rs}}(\lambda)}{1-1.5 r_{\mathrm{rs}}(\lambda)} .
$$

In Case II Water, the total absorption $a(\lambda)$ includes the absorption of seawater $a_{w}$, phytoplankton $a_{\mathrm{ph}}(\lambda)$, and colored dissolved and detrital organic matters $a_{\mathrm{cdm}}(\lambda)$ :

$$
a(\lambda)=a_{w}(\lambda)+a_{\mathrm{ph}}(\lambda)+a_{\mathrm{cdm}}(\lambda)
$$

The total backscattering coefficient $b_{b}(\lambda)$ is the scalar sum of the backscatter values by pure water $b_{b w}(\lambda)$ and particulates $b_{b p}(\lambda)$ :

$$
b_{b}(\lambda)=b_{b w}(\lambda)+b_{b p}(\lambda)
$$

where $b_{b p}(\lambda)$ is defined as

$$
b_{b p}(\lambda)=b_{b p}\left(\lambda_{0}\right)\left(\frac{\lambda_{0}}{\lambda}\right)^{Y} .
$$

$b_{b p}\left(\lambda_{0}\right)$ is the particulate backscattering coefficient at the scaling wavelength $\lambda_{0}$. $Y$ is the spectral slope of particulate backscattering coefficient.

According to (1)-(5), several semiempirical and semianalytical algorithms have been proposed for deriving the IOPs. The algorithms typically used include the GarverSiegel-Maritorena (GSM) algorithm [36-38] and the quasianalytical algorithm (QAA) [39-41]. Thus, the existing models often differ only in the assumptions employed to define the eigenvectors. To facilitate a controlled evaluation of these various approaches, the NASA Ocean Biology Processing Group (OBPG) recently developed the Generalized IOP (GIOP) model that allows users to choose different IOP models by selecting from a wide assortment of published eigenvectors for constituent absorption and scattering properties [42, 43].

\section{Methods}

3.1. Phytoplankton Cultures. Aureococcus anophagefferens (A. anophagefferens) is a $2-3 \mu \mathrm{m}$ spherical, nonmotile pelagophyte that has caused harmful brown tide blooms for extended periods in estuaries in the northeast and midAtlantic US [44], and the species was also found in the coastal seas of China in recent years.

The cultures were supplied by the Marine Biology Group of the National Marine Environmental Monitoring Center and were grown in an $\mathrm{f} 2$-enriched medium that was sterilized and filtered using $0.45 \mu \mathrm{m}$ filter membranes. The cultures were incubated under banks of cool white fluorescent bulbs at $23 \pm 1^{\circ} \mathrm{C}$ under a $12: 12$ dark: light cycle. A Hydrolab water quality instrument was placed in the culturing vat to observe the phytoplankton growth status continuously, and a collection frequency of $1 \mathrm{~h}$ was adopted. These cultures were not axenic, and the exponential growth of the cells was maintained by diluting them as needed with fresh media. 
3.2. Measurement of Inherent Optical Properties. Measurements of spectral backscattering were carried out at $140^{\circ}$ and six wavelengths $(420,442,488,550,620$, and $700 \mathrm{~nm})$ with the Hydroscat-6 instrument (HS-6, HOBI Labs, Inc.). The measurements were conducted in a $400 \times 400 \times 500 \mathrm{~mm}^{3}$ (length, width, and height) Plexiglass box built to replicate the manufacturer's standard calibration chamber. The face of the HS-6 instrument was immersed approximately $1 \mathrm{~cm}$ below the air-water interface, which was $27 \mathrm{~cm}$ from the container bottom [45]. An ac-s (WET Labs, Inc.) was attached in line with the calibration chamber and the sample medium was circulated through the system with a small pump. The measurements were recorded when stable absorption and attenuation readings were obtained. During each experiment, the container was covered with an opaque black cloth and a piece of black glass was placed below the Plexiglass box in order to prevent extraneous light from entering the container.

Serial dilution tests with the culture were conducted to check for the linearity of response over the chlorophyll concentrations. At the beginning of the experiments, the container was filled with $50 \mathrm{~L}$ of $0.2 \mu \mathrm{m}$ filtered seawater for marine alga. Firstly, a steady clean-water baseline for each instrument was established, which was expected to represent the possible effects of the container or filtered media. Next, $500 \mathrm{~mL}$ to $1000 \mathrm{~mL}$ of the culture was added to the container and the measurements were taken after the algal suspension was thoroughly mixed. Sequential additions of culture were conducted in this fashion until the entire volume had been added. Lastly, the bigger error data were excluded and seven samples at different chlorophyll concentrations were used to analyse the optical properties of $A$. anophagefferens.

3.3. Measurement of Apparent Optical Properties. After each measurement of inherent optical properties, the water samples were placed in a bucket. In order to simulate the optical environment of deep water and avoid incident light potentially reflected by the barrel wall entering the water, the internal wall was painted with a black lacquer. At the same time, we chose the open area as the measurement site and all of the measurements were taken between 9:00 and 14:00 $\mathrm{h}$ local time.

The remote sensing reflectance $\left(R_{\mathrm{rs}}\right)$ spectra were derived from upwelling radiance and downwelling irradiance acquired by an ASD FieldSec spectral radiometer. With a field view of $25^{\circ}$, this instrument has a sensitivity range of $380-$ $1050 \mathrm{~nm}$. The resolution was transformed into $1 \mathrm{~nm}$ by the accompanying software. The measurement followed the Ocean Optical Protocols (Revision 3) by NASA (2002). Downwelling solar irradiance $E_{s}\left(0^{+}\right)$measurements were performed using a Spectralon standard plate and the abovewater upwelling radiance $L_{\text {sfc }}\left(0^{+}\right)$was observed with an azimuth viewing direction of $135^{\circ}$ from the sun and a nadir angle of $45^{\circ}$. The same parameters were used to measure the sky diffuse radiance $L_{\text {sky }}\left(0^{+}\right)$, including the same azimuth angle $\left(135^{\circ}\right)$, but with a zenith angle of $45^{\circ}$. For each radiometric measurement, at least seven continuous values were

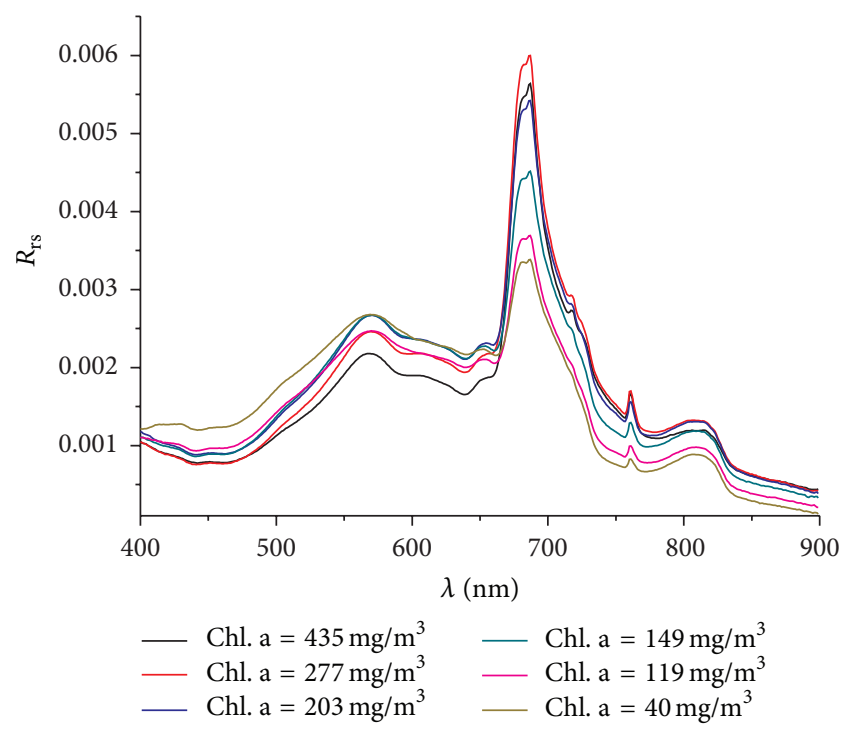

Figure 1: The remote sensing reflectance spectrum of Aureococcus anophagefferens.

recorded to produce an average value. $R_{\mathrm{rs}}$ was calculated according to Mueller and Fargion [46] by

$$
R_{\mathrm{rs}}=\frac{L_{w}\left(0^{+}\right)}{E_{s}\left(0^{+}\right)}=\frac{L_{\mathrm{sfc}}\left(0^{+}\right)-\rho L_{\mathrm{sky}}\left(0^{+}\right)}{E_{s}\left(0^{+}\right)},
$$

where $L_{w}\left(0^{+}\right)$is the water-leaving radiance and $\rho$ represents the reflectance of the skylight at the air-water interface. This value depends on the solar azimuth angle, wind speed, and cloud coverage. Under cloud-free and low wind speed (less than $10 \mathrm{~m} \mathrm{~s}^{-1}$ ) conditions, $\rho$ may be treated as independent of wavelength. When wind speeds are less than $5 \mathrm{~m} \mathrm{~s}^{-1}$, the $\rho$ value was chosen to be 0.028 [47].

The $R_{\mathrm{rs}}$ spectra of $A$. anophagefferens recorded at different chlorophyll concentrations are shown in Figure 1. A reflection peak appeared near $550 \mathrm{~nm}$ and a chlorophyll fluorescence peak emerged at $700 \mathrm{~nm}$. As the chlorophyll concentration increased, the peaks became more and more obvious.

The field ASD $R_{\mathrm{rs}}(\lambda)$ was used to derive the equivalent $R_{\mathrm{rs}}$ of MODIS bands via the MODIS spectral response function. The specific formula is as follows:

$$
\left\langle R_{\mathrm{rs}}\left(\lambda_{i}\right)\right\rangle=\frac{\int_{380 \mathrm{~nm}}^{1050 \mathrm{~nm}} R_{\mathrm{rs}}(\lambda) F_{s}(\lambda) S_{i}(\lambda) \mathrm{d} \lambda}{\int_{380 \mathrm{~nm}}^{1050 \mathrm{~nm}} F_{s}(\lambda) S_{i}(\lambda) \mathrm{d} \lambda},
$$

where $\left\langle R_{\mathrm{rs}}\left(\lambda_{i}\right)\right\rangle$ is the equivalent $R_{\mathrm{rs}}$ at a central wavelength $\lambda_{i}, F_{s}(\lambda)$ is the mean solar radiative flux at the top of the atmosphere, and $S_{i}(\lambda)$ is the spectral response function at the wavelength $\lambda_{i}$ (http://oceancolor.gsfc.nasa.gov/DOCS/ RSR_tables.html).

3.4. Ancillary Measurements. Chlorophyll a concentration was determined by a high-performance liquid chromatography (HPLC) analysis following the procedure described by Van Heukelem and Thomas [48]. Culture samples were 


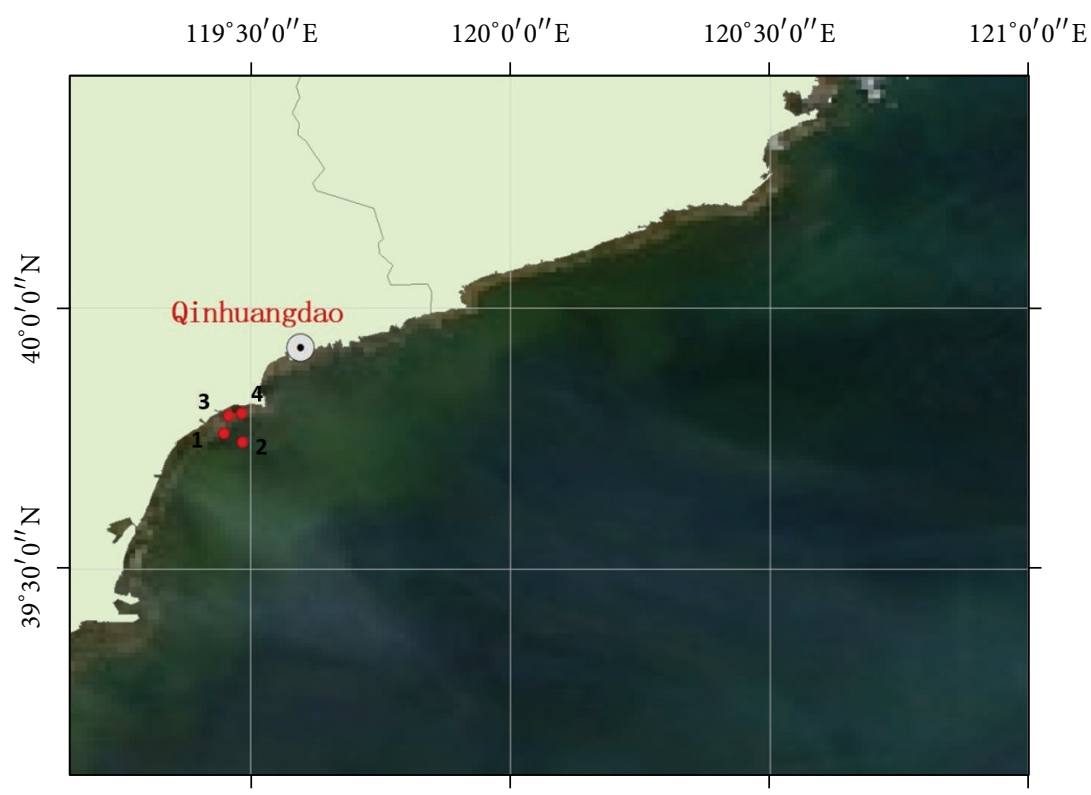

FIGURE 2: The MODIS data of study region and the stations (solid circles) in the Bohai Sea around Qinhuangdao of China.

TABLE 1: Summary of A. anophagefferens backscattering characteristics.

\begin{tabular}{lccc}
\hline Bands & \multicolumn{2}{c}{ Backscattering coefficients } & $b^{*}{ }_{b p} \times 10^{3} \mathrm{~m}^{2}$ \\
& $b_{b p}(\lambda)\left(\mathrm{m}^{-1}\right)$ & Amplitude of variation & $(\mathrm{mgchla})^{-1}$ \\
\hline 420 & $0.0044-0.1639$ & 36.25 & 0.570 \\
442 & $0.0042-0.1432$ & 33.09 & 0.527 \\
488 & $0.0041-0.1616$ & 38.41 & 0.538 \\
550 & $0.0029-0.0920$ & 30.72 & 0.341 \\
620 & $0.0030-0.0934$ & 30.13 & 0.353 \\
700 & $0.0029-0.0818$ & 27.21 & 0.324 \\
\hline
\end{tabular}

filtered with GF/F filters prior to the optical measurements and frozen in cryotubes in liquid nitrogen until the analysis time. Cell counts of $A$. anophagefferens were performed using a high-power fluorescent microscope.

3.5. Satellite Data. Sampling was conducted in Bohai and adjacent coastal waters around Qinhuangdao city on June 6, 2012. Sampling stations are shown in Figure 2. The software SEADAS6.2 MODIS was used to process the L1B-L2 data with the atmosphere correction. We also chose the 2-band model option and an iterative NIR correction for the Aerosol mode with the other options on their default settings. Only cloud-free images were used for the cell density assessment.

\section{Results and Discussion}

4.1. Spectral Particulate Backscattering Coefficients. This is the first report of particulate backscattering coefficients at different chlorophyll concentrations, $b_{b p}(\lambda)$, for the red tide algae $A$. anophagefferens (Table 1, Figure 3 ). The backscattering coefficient value at each band increased with an increase

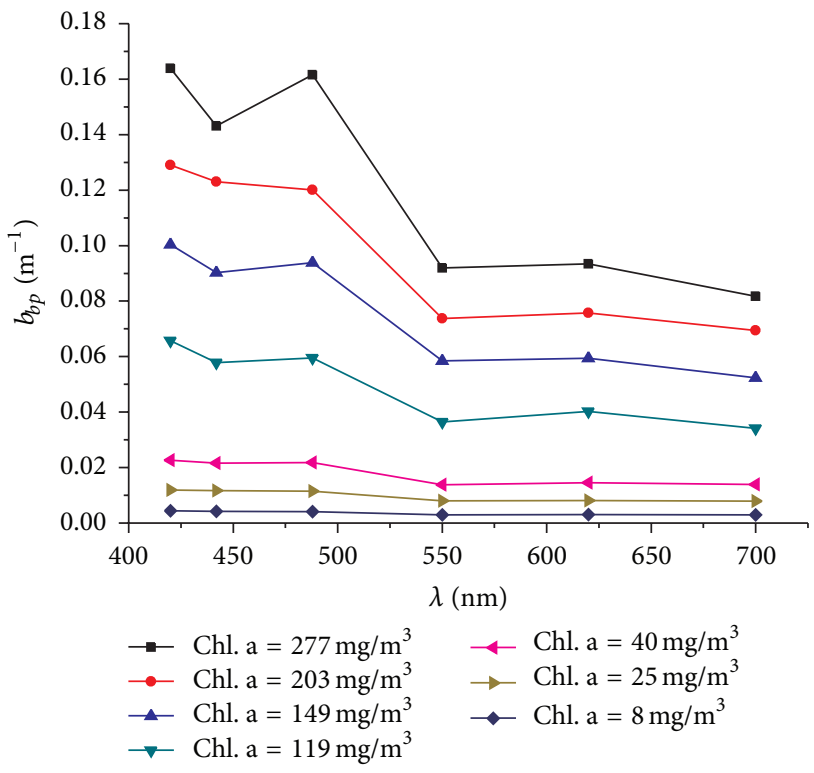

FIGURE 3: Spectral values of backscattering coefficients of $A$. anophagefferens. (Solid points are averaged data.)

in chlorophyll concentration and the amplitude of variation was larger than that of the nanophytoplankton [49-51]. The shape of the particulate backscattering coefficient spectra changed with increases in the chlorophyll concentrations in the visible range; although the maximum $b_{b p}$ value was observed at $420 \mathrm{~nm}$, the minimum value occurred at $550 \mathrm{~nm}$ for any chlorophyll concentration. An obvious depression at $442 \mathrm{~nm}$ appeared at high chlorophyll concentrations because of pigment absorption, consistent with the results of Stramski et al. [52]. Other research has shown that measurements of backscattering at $676 \mathrm{~nm}$ can be artificially elevated by 
TABLE 2: Simulated results of double-band model.

\begin{tabular}{lccc}
\hline \multirow{2}{*}{ Bands } & & Independent variable & \\
& $R_{\mathrm{rs}}(443) / R_{\mathrm{rs}}(488)$ & $R_{\mathrm{rs}}(488) / R_{\mathrm{rs}}(678)$ & $R_{\mathrm{rs}}(551) / R_{\mathrm{rs}}(678)$ \\
\hline \multirow{2}{*}{$420 \mathrm{~nm}$} & $Y=15.13-21.06 x$ & $Y=-1.11+5.20 x$ & $Y=-1.55+3.55 x$ \\
& $R^{2}=0.42$ & $R^{2}=0.36$ & $R^{2}=0.52$ \\
\hline \multirow{2}{*}{$443 \mathrm{~nm}$} & $Y=-4.69+6.23 x$ & $Y=-0.72+1.74 x$ & $R^{2}=-0.18$ \\
\hline \multirow{2}{*}{$551 \mathrm{~nm}$} & $R^{2}=-0.2$ & $Y=5.58-4.75 x$ & $Y=6.02-3.32 x$ \\
& $Y=-7.93+17.37 x$ & $R^{2}=-0.18$ & $R^{2}=0.55$ \\
\hline \multirow{2}{*}{$620 \mathrm{~nm}$} & $R^{2}=0.27$ & $Y=3.27-4.70 x$ & $Y=3.60-3.06 x$ \\
& $Y=-8.10+14.37 x$ & $R^{2}=0.65$ & $R^{2}=0.77$ \\
\hline
\end{tabular}

$Y$ is the spectral slope of particulate backscattering coefficient; $x$ is reflectance ratio.

the fluorescent emission to detect backscattering at this wavelength [53-55]. However, the data we obtained at $620 \mathrm{~nm}$ were only a little higher than values at $700 \mathrm{~nm}$ and so we conclude there was no contamination of the signal by chlorophyll fluorescence.

In order to compare our results with others, we calculated the chlorophyll-specific backscattering coefficient, $b^{*}{ }_{b p}$, with the units $\mathrm{m}^{2} \mathrm{mg} \mathrm{chl} \mathrm{a}^{-1}$ (Table 1 ). This represents the backscattering coefficient of the suspended cells at a concentration of $1 \mathrm{mg} \mathrm{m}^{-3}$ chlorophyll a. $b^{*}{ }_{b p}(442)$ and $b^{*}{ }_{b p}(620)$ were 0.000527 and 0.000353 , respectively. This is lower than the backscattering coefficient of microbial cultures reported by Whitmire et al. [55] and Vaillancourt et al. [45] that were measured by HS-6 due to their relatively small particles. The spectral characteristics of $A$. anophagefferens are unique compared to measurements obtained by other researchers for phytoplankton $[45,49-52,55,56]$. Our results are a good theoretical basis for future studies on picoplankton identification.

4.2. Backscattering Coefficient and Cell Density. Mie theory indicates that the backscattering coefficient is closely related to the cell size, density, composition, and refractive index [57]. Thus, particle density was one of the main factors that influenced the backscattering coefficient measurements. As particle density was a primary indicator of algal bloom, establishing the relationship between particle density and the backscattering coefficient could improve the accuracy of identifying red tide algae by remote sensing measurements of water color.

We found that there was a strong relationship between cell density and the backscattering coefficient that satisfies the following equation:

$$
\lg N=a b_{b}\left(\lambda_{0}\right)^{c}
$$

where $N$ is cell density recorded as cells/mL; $a$ and $c$ are the regression model parameters; and $b_{b}\left(\lambda_{0}\right)$ is the backscattering coefficient at each band. The regression coefficients were large at each band, with a minimum value of 0.97 at $488 \mathrm{~nm}$ and a maximum value of 0.98 at other bands (Figure 4).

4.3. Modeled Relationship between $R_{r s}(\lambda)$ and $b_{b}(\lambda)$. The bands $488 \mathrm{~nm}$ and $551 \mathrm{~nm}$ were selected as the representative
MODIS central bands, on the basis of the way the relation model was constructed by using the measured data and the biooptical theoretical analysis model (see Figure 5). We found a linear relationship between the backscattering coefficient and the remote sensing reflectance, with a regression coefficient of 0.89 at $488 \mathrm{~nm}$ and 0.57 at $551 \mathrm{~nm}$. For this reason, $488 \mathrm{~nm}$ was chosen as the reference band to build the cell density inversion model.

For a comparison and a potentially more accurate model, a two-band ratio algorithm was also used and the MODIS bands b9 $(443 \mathrm{~nm})$, b10 $(488 \mathrm{~nm})$, b12 $(551 \mathrm{~nm})$, and b14 $(678 \mathrm{~nm})$ were selected to establish the relationship between the spectral slope of the particulate backscattering coefficient and reflectance:

$$
Y \propto \frac{R_{\mathrm{rs}}\left(\lambda_{1}\right)}{R_{\mathrm{rs}}\left(\lambda_{2}\right)} .
$$

In this study, $R_{\mathrm{rs}}(443) / R_{\mathrm{rs}}(488), R_{\mathrm{rs}}(488) / R_{\mathrm{rs}}(678)$, and $R_{\mathrm{rs}}(551) / R_{\mathrm{rs}}(678)$ were chosen to be studied and the simulated results were as in Table 2 .

Our results demonstrate no significant correlation between each band ratio and backscattering spectra at $443 \mathrm{~nm}$. The strongest correlation appeared between the ratio $R_{\mathrm{rs}}(551) / R_{\mathrm{rs}}(678)$ and the backscattering spectra with a maximum regression coefficient of 0.77 at $620 \mathrm{~nm}$. Therefore, we combined the simulated results of cell density and backscattering coefficients and the cell density inversion model was as follows:

$$
\begin{aligned}
b_{b p}(\lambda) & =b_{b}\left(\lambda_{0}\right)\left(\frac{\lambda_{0}}{\lambda}\right)^{Y}, \\
b_{b}\left(\lambda_{0}\right) & =0.75-568.55 R_{\mathrm{rs}}\left(\lambda_{0}\right), \\
Y & =3.60-3.06 \frac{R_{\mathrm{rs}}(551)}{R_{\mathrm{rs}}(678)}, \\
\lg N & =10.299 \cdot b_{b p}(\lambda)^{0.055},
\end{aligned}
$$

where $\lambda_{0}$ is at $488 \mathrm{~nm}$ and $\lambda$ is at $620 \mathrm{~nm}$.

4.4. Application of the Forward Model. By utilizing the cell density parameterizations of the IOPs, the model described 


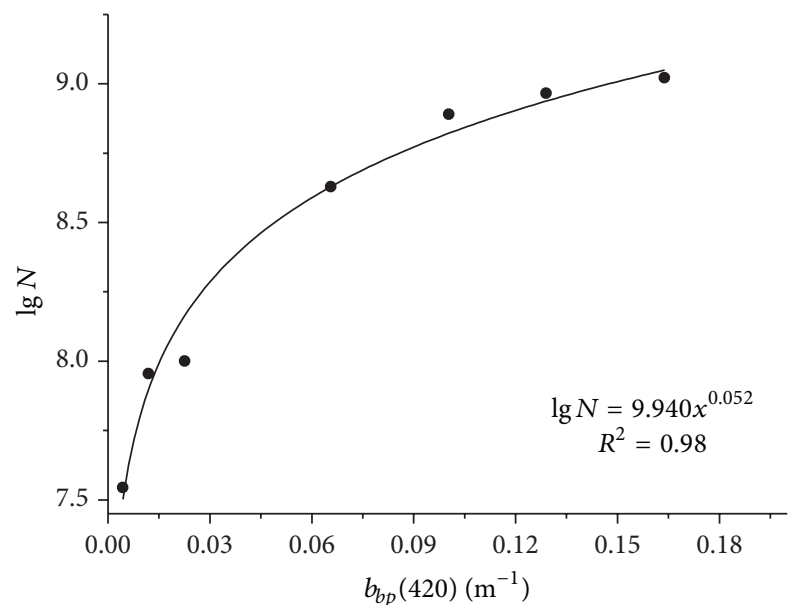

(a)

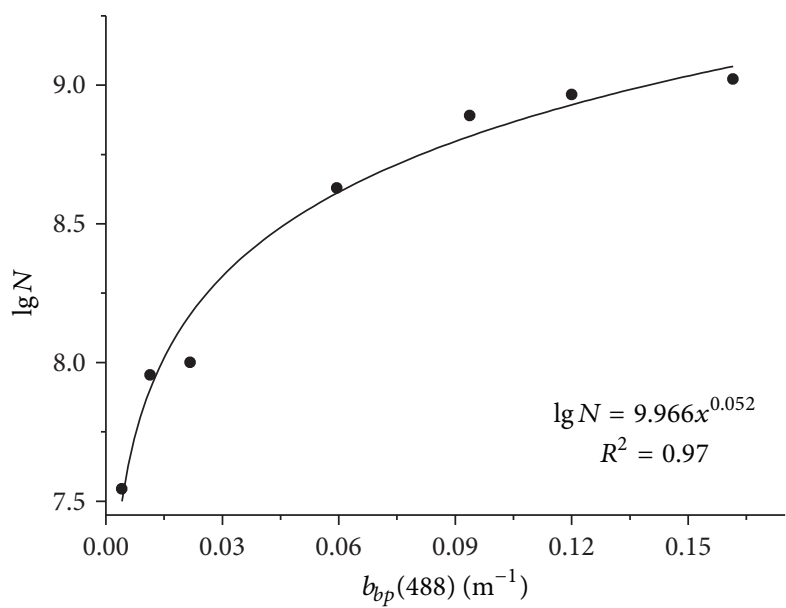

(c)

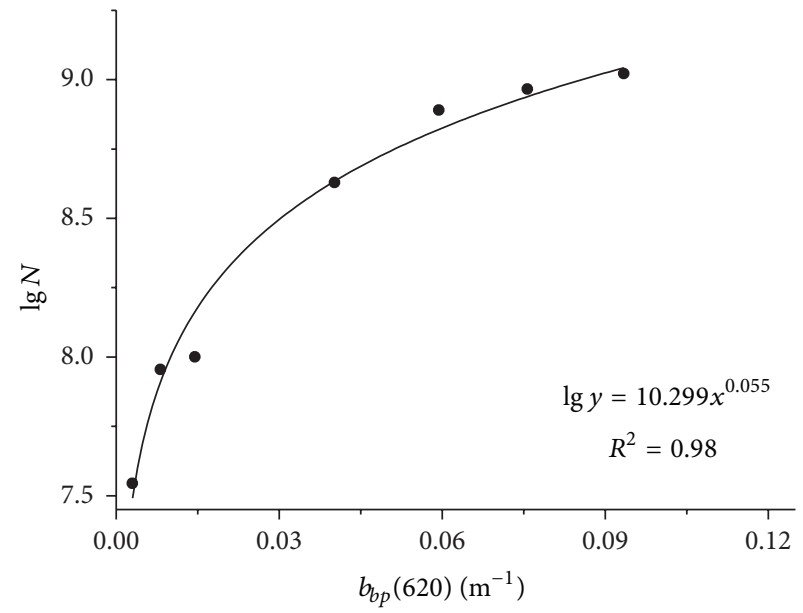

(e)

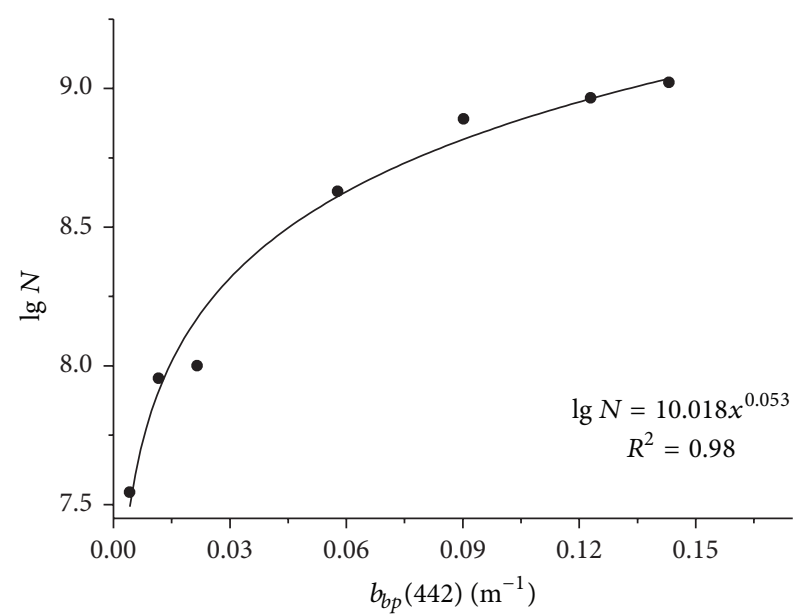

(b)

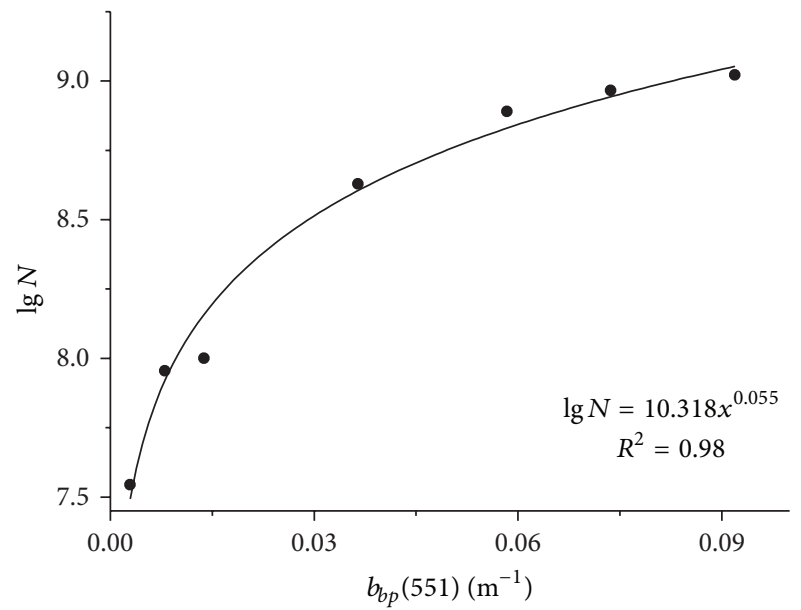

(d)

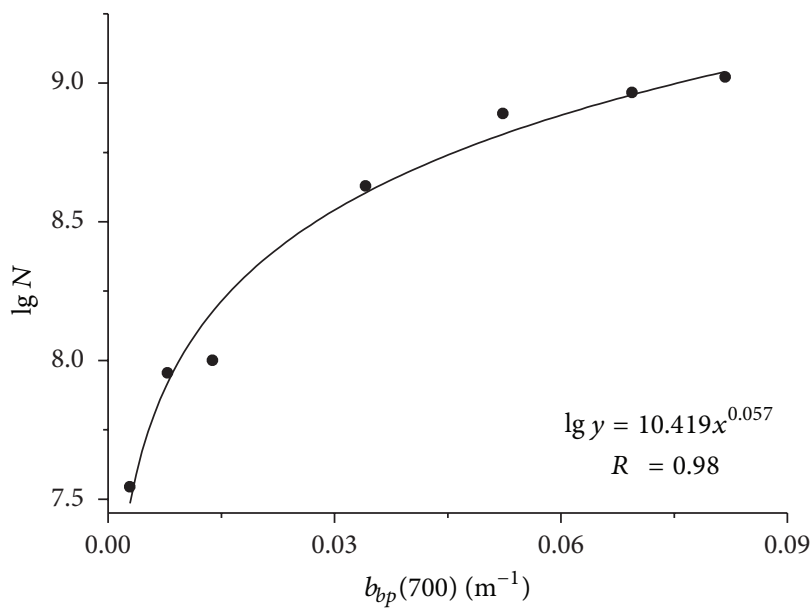

(f)

FIGURE 4: Particle backscattering coefficients versus cell density at six other wavelengths for Aureococcus anophagefferens. (a) $420 \mathrm{~nm}$. (b) $442 \mathrm{~nm}$. (c) $488 \mathrm{~nm}$. (d) $550 \mathrm{~nm}$. (e) $620 \mathrm{~nm}$. (f) $700 \mathrm{~nm}$. 


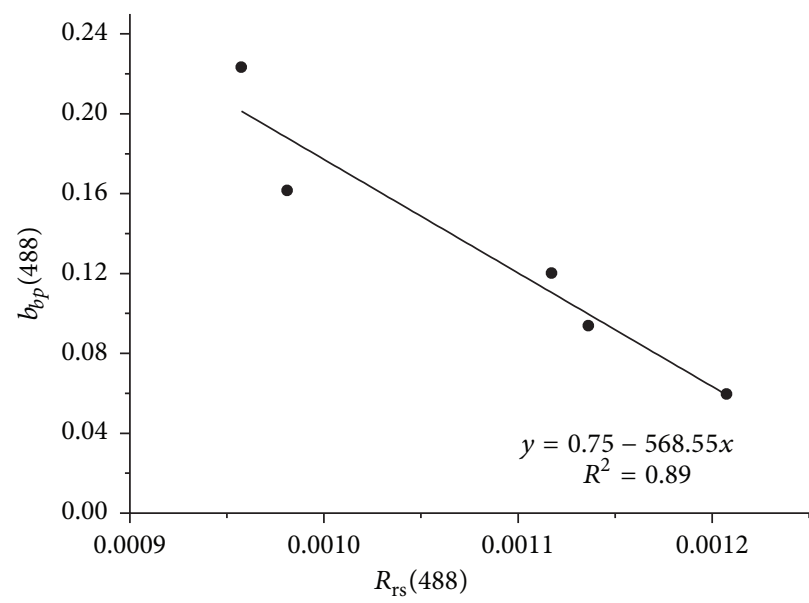

(a)

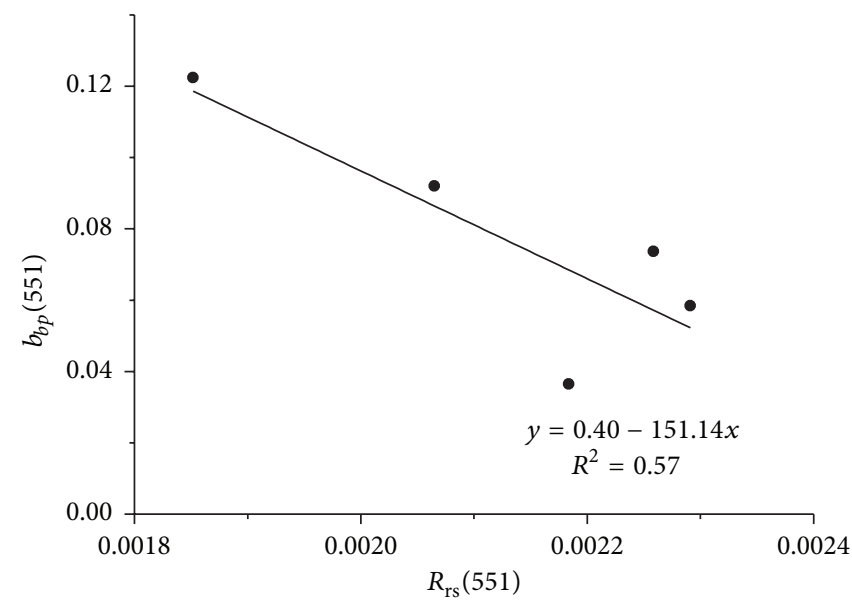

(b)

FIGURE 5: The backscattering coefficient versus remote sensing reflectance. (a) At $488 \mathrm{~nm}$. (b) At $551 \mathrm{~nm}$.

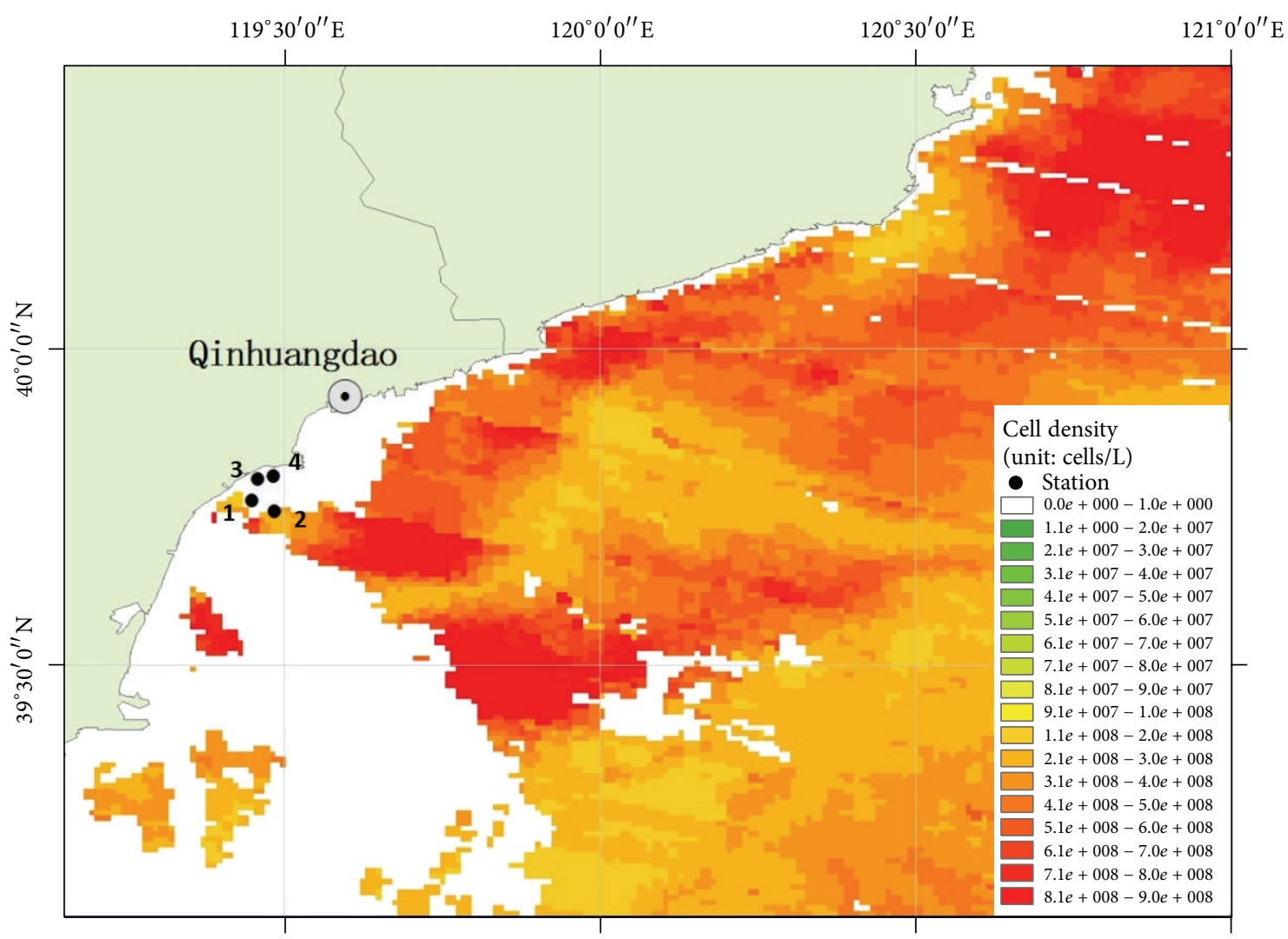

FIGURE 6: Cell density distribution of using multiband inversion model.

in (10) can be used to compute the $R_{\mathrm{rs}}(\lambda)$ spectra for various cell density values. However, we found that the forecasted $b_{b}\left(\lambda_{0}\right)$ overestimated the true value because of a steeper slope between $b_{b}\left(\lambda_{0}\right)$ and $R_{\mathrm{rs}}\left(\lambda_{0}\right)$ in (10). Therefore, three semianalytical algorithms (GSM, QAA, and GIOP) were trialed to calculate a corrected $b_{b}\left(\lambda_{0}\right)$. These results indicated that $b_{b}\left(\lambda_{0}\right)$ calculated by GSM and QAA was too high, but the value calculated by the GIOP method was similar to the measured result. On this basis, the GIOP semianalytical model was chosen to predict $b_{b}\left(\lambda_{0}\right)$ by $R_{\mathrm{rs}}\left(\lambda_{0}\right)$ and the cell density distribution was obtained for a given sea area (Figure 6).

The inversion values of cell density were similar to the field measurements at stations 1 and 2 (Table 3), the average relative error was only $8.9 \%$, and there were no results at stations 3 and 4 because of cloud cover, while in offshore 
TABLE 3: Comparison of monitoring result and inversion result (cells/L).

\begin{tabular}{lcccc}
\hline Stations & $\begin{array}{c}\text { Longitude and } \\
\text { latitude }\end{array}$ & $\begin{array}{c}\text { Cell density by } \\
\text { measurement }\end{array}$ & $\begin{array}{c}\text { Cell density calculated by the } \\
\text { multiband inversion model }\end{array}$ & $\begin{array}{c}\text { Cell density calculated by the } \\
\text { single-band inversion model }\end{array}$ \\
\hline 1 & $\begin{array}{c}119^{\circ} 26.989^{\prime} \mathrm{E} \\
39^{\circ} 45.488^{\prime} \mathrm{N}\end{array}$ & $2.65 \times 10^{8}$ & $2.60 \times 10^{8}$ & $1.47 \times 10^{8}$ \\
\hline 2 & $\begin{array}{l}119^{\circ} 26.111^{\prime} \mathrm{E} \\
39^{\circ} 44.488^{\prime} \mathrm{N}\end{array}$ & $2.53 \times 10^{8}$ & $2.78 \times 10^{8}$ & $1.307 \times 10^{8}$ \\
\hline 3 & $119^{\circ} 29.000^{\prime} \mathrm{E}$ & No result & No result \\
\hline 4 & $39^{\circ} 47.833^{\prime} \mathrm{N}$ & $3.62 \times 10^{8}$ & No result & No result \\
\hline
\end{tabular}

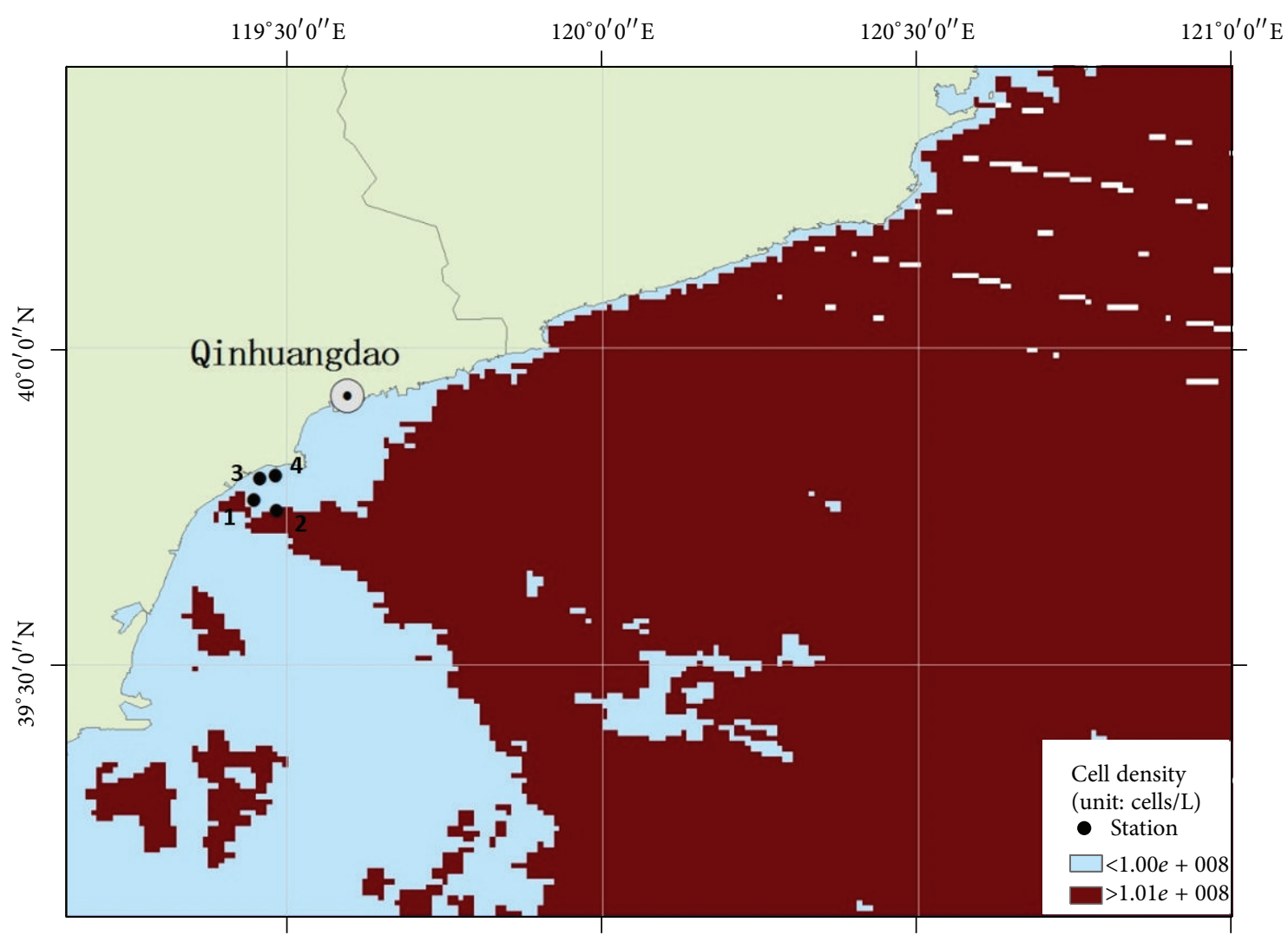

FIgURE 7: The distribution area of the Aureococcus anophagefferens red tide (multiband inversion).

waters the value was higher so that the red tide range was larger than the actual scope (Figure 7). In view of this, the single-band cell density remote sensing inversion model was established (Figures 8 and 9), in which $488 \mathrm{~nm}$ was the reference band $\lambda_{0}$, the relationship model between $b_{b}\left(\lambda_{0}\right)$ and $R_{\mathrm{rs}}\left(\lambda_{0}\right)$ was also determined by GIOP semianalytical model, and the formula $\lg N=9.966 \cdot b_{b p}\left(\lambda_{0}\right)^{0.052}$ forms the simultaneous equations. By comparing the two methods, we found that the red tide distribution range for the whole sea area was more consistently computed by the singleband inversion model, but for the calculated values of the coastal waters, the average relative error was higher than that computed by the multiband inversion model. The main reason was that the multiband inversion model is more precise only in dense chlorophyll waters and it is difficult to discern the red tide accurately from mixed pixels; however, the single-band inversion model just could eliminate the impact of the suspended sediments and make more accurate estimates of the red tide area.

\section{Conclusions}

Improvements in technological instrumentation, combined with the growing availability of large biooptical data sets, are resulting in the increasing use of remote sensing data to monitor red tides. This is carried out by algorithms to describe empirical relationships between oceanic reflectance and phytoplankton pigment concentrations. In fact, cell density plays an important role in recognizing red tides in the field and cell density has a large effect on the backscattering 


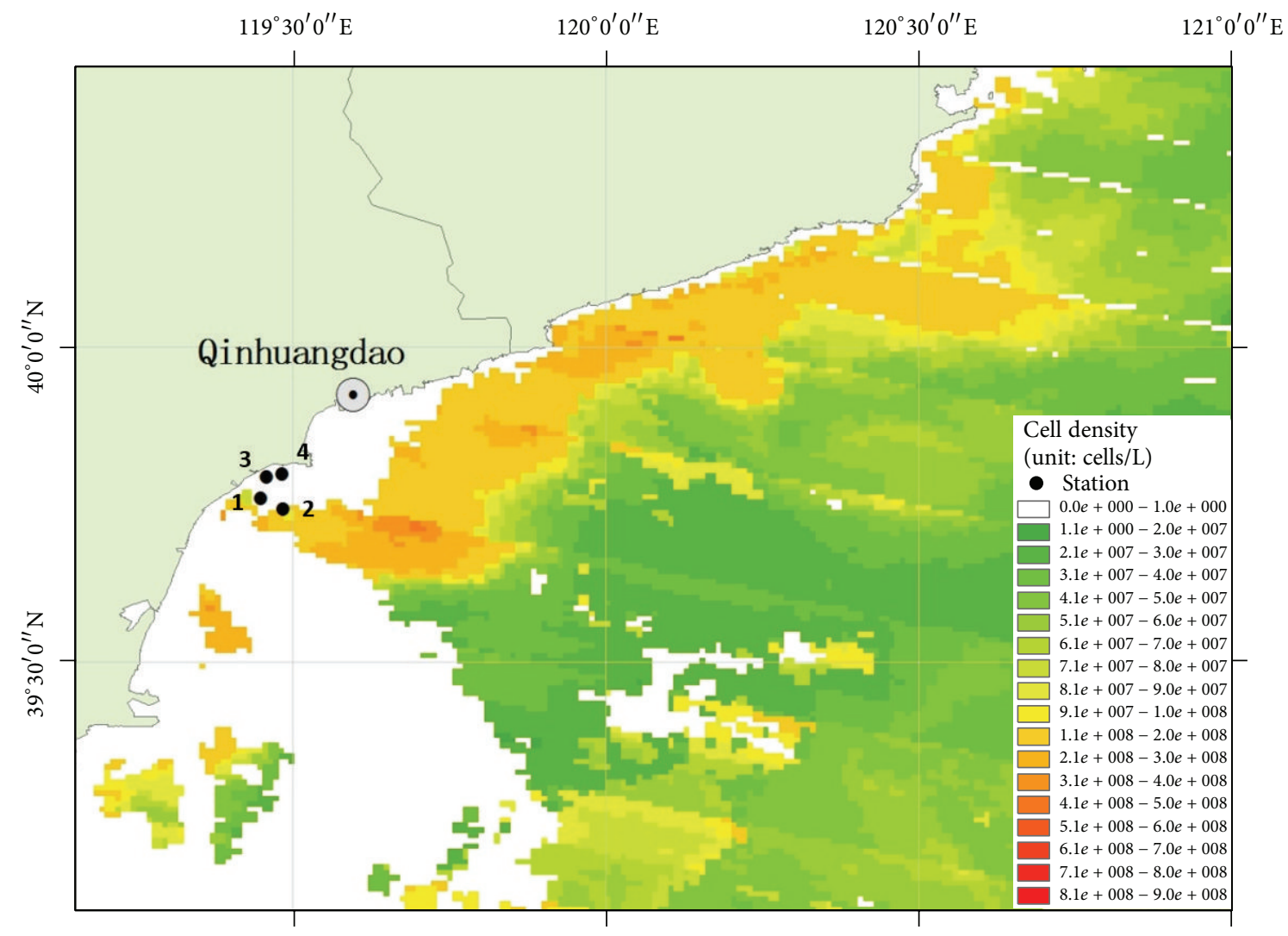

FIGURE 8: Cell density distribution of using single-band inversion model.

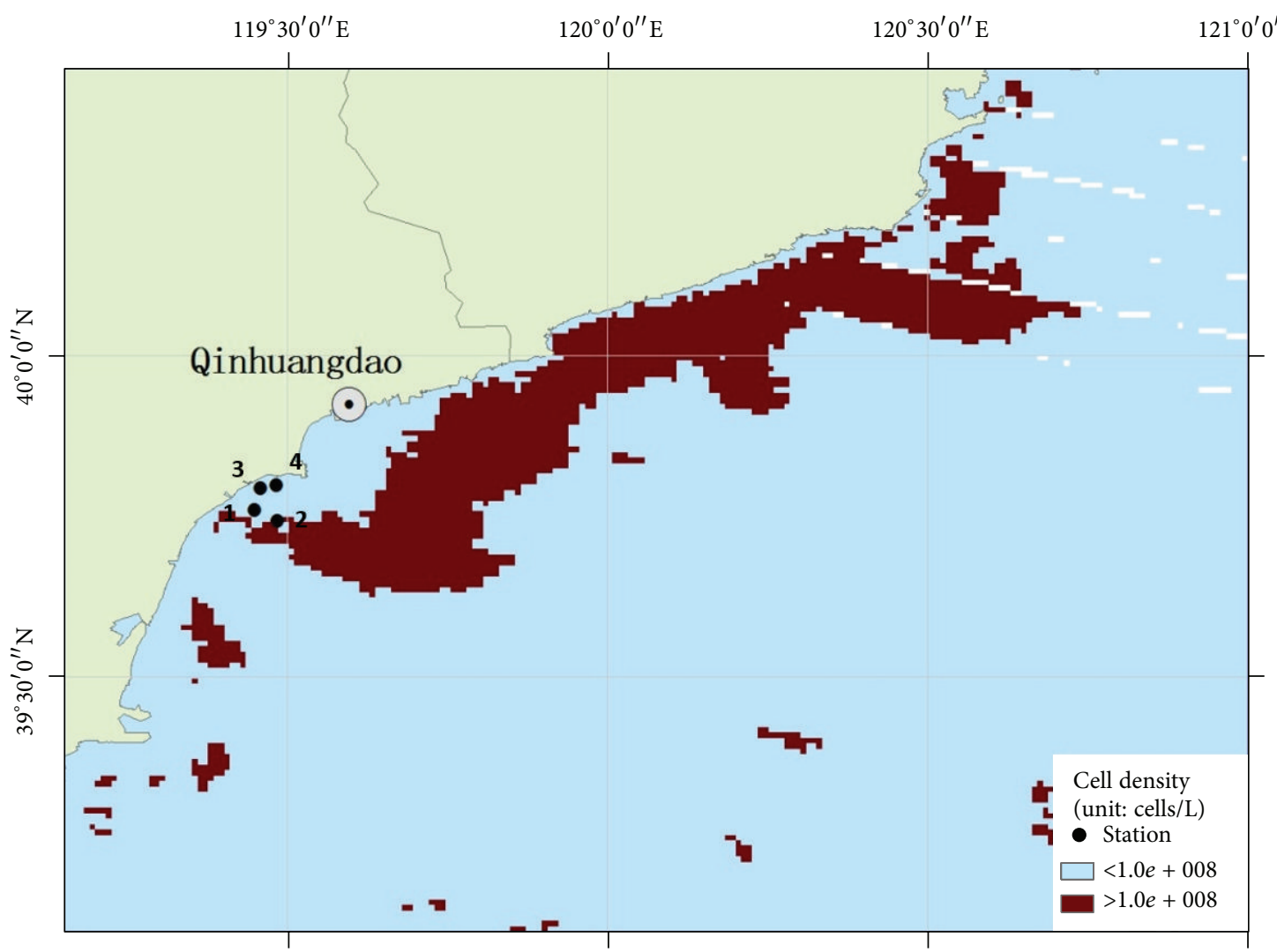

Figure 9: The distribution area of the Aureococcus anophagefferens red tide (single-band inversion). 
properties of algae. Moreover, only a few models used to monitor red tides are based on the relationship between oceanic reflectance and cell density. In the present study, the backscattering properties of $A$. anophagefferens were examined and an empirical relationship between cell density and backscattering coefficients was found, in which the minimum regression coefficient was 0.97 at $488 \mathrm{~nm}$. Additionally, the reflectance spectra were obtained, and with these values, single-band and multiband cell density inversion semianalytical models were employed, according to the MODIS central bands.

We used in situ measurement data to examine the accuracy and precision of models to predict red tides and found differences between the qualities of the models. Our results demonstrate that the cell densities calculated by the singleband inversion model are lower than those measured on site, but this bias is caused by suspended sediments. Although the value computed by the multiband inversion model was closer to the field-measured data, it could not accurately discern the red tide area in mixed pixels. In conclusion, cell density remote sensing inversion models have the potential to play a larger role in monitoring red tides in the future if they could distinguish inorganic particulate matter and phytoplankton from waters.

\section{Conflict of Interests}

The authors declare that there is no conflict of interests regarding the publication of this paper.

\section{Acknowledgments}

The authors thank the Marine Biology Group of the National Marine Environmental Monitoring Center for providing and cultivating the algal species and also the members of their team for helping them take the measurements. This work was supported by the National Marine Public Welfare Research Project of China under Grant no. 201305003, the National Natural Science Foundation of China under Grant no. 41276105, and the Fundamental Research Funds for the Central University under Grant no. 3132015081.

\section{References}

[1] D. M. Anderson, P. M. Glibert, and J. M. Burkholder, "Harmful algal blooms and eutrophication: nutrient sources, composition, and consequences," Estuaries, vol. 25, no. 4, pp. 704-726, 2002.

[2] D. M. Anderson, "Approaches to monitoring, control and management of harmful algal blooms (HABs)," Ocean and Coastal Management, vol. 52, no. 7, pp. 342-347, 2009.

[3] K. D. Haddad, Hydrographic factors associated with west Florida toxic red tide blooms: an assessment for satellite prediction and monitoring [M.S. thesis], University of South Florida, St. Petersburg, Fla, USA, 1982.

[4] J. J. Cullen, Á. M. Ciotti, R. F. Davis, and M. R. Lewis, "Optical detection and assessment of algal blooms," Limnology and Oceanography, vol. 42, no. 5, pp. 1223-1239, 1998.
[5] P. A. Tester and R. P. Stumpf, "Phytoplankton blooms and remote sensing: what is the potential for early warning," Journal of Shellfish Research, vol. 17, no. 5, pp. 1469-1471, 1998.

[6] O. Schofield, J. Grzymski, W. P. Bissett et al., "Optical monitoring and forecasting systems for harmful algal blooms: possibility or pipe dream?" Journal of Phycology, vol. 35, no. 6, pp. 14771496, 1999.

[7] D. L. Pan, T. M. Mao, S. J. Li, and H. Huang, "Study on detection of coastal water environment of China by ocean color remote sensing," Acta Oceanologica Sinica, vol. 20, no. 1, pp. 51-63, 2001.

[8] X. H. Xu, D. L. Pan, Z. H. Mao, and B. Y. Tao, "A new algorithm based on the background field for red tide monitoring in the East China Sea," Acta Oceanologica Sinica, vol. 33, no. 5, pp. 6271, 2014.

[9] R. P. Stumpf, M. E. Culver, P. A. Tester et al., "Monitoring Karenia brevis blooms in the Gulf of Mexico using satellite ocean color imagery and other data," Harmful Algae, vol. 2, no. 2, pp. 147-160, 2003.

[10] M. C. Tomlinson, R. P. Stumpf, V. Ransibrahmanakul et al., "Evaluation of the use of SeaWiFS imagery for detecting Karenia brevis harmful algal blooms in the eastern Gulf of Mexico," Remote Sensing of Environment, vol. 91, no. 3-4, pp. 293-303, 2004.

[11] M. C. Tomlinson, T. T. Wynne, and R. P. Stumpf, "An evaluation of remote sensing techniques for enhanced detection of the toxic dinoflagellate, Karenia brevis," Remote Sensing of Environment, vol. 113, no. 3, pp. 598-609, 2009.

[12] C. Hu, F. E. Muller-Karger, C. Taylor et al., "Red tide detection and tracing using MODIS fluorescence data: a regional example in SW Florida coastal waters," Remote Sensing of Environment, vol. 97, no. 3, pp. 311-321, 2005.

[13] Y.-H. Ahn and P. Shanmugam, "Detecting the red tide algal blooms from satellite ocean color observations in optically complex Northeast-Asia Coastal waters," Remote Sensing of Environment, vol. 103, no. 4, pp. 419-437, 2006.

[14] J. Ishizaka, Y. Kitaura, Y. Touke et al., "Satellite detection of red tide in Ariake Sound, 1998-2001," Journal of Oceanography, vol. 62, no. 1, pp. 37-45, 2006.

[15] R. P. Stumpf, "Applications of satellite ocean color sensors for monitoring and predicting harmful algal blooms," Human and Ecological Risk Assessment, vol. 7, no. 5, pp. 1363-1368, 2001.

[16] F. H. Chang, M. Uddstrom, and M. Pinkerton, "Studies of the winter 2000 Gymnodinium catenatum outbreaks in New Zealand using remotely sensed sea surface temperature and chlorophyll a data from satellites," in Proceedings of the Marine Biotoxin Science Workshop, vol. 15, pp. 165-173, May 2001.

[17] A. A. Gitelson, J. F. Schalles, and C. M. Hladik, "Remote chlorophyll-a retrieval in turbid, productive estuaries: Chesapeake Bay case study," Remote Sensing of Environment, vol. 109, no. 4, pp. 464-472, 2007.

[18] J. E. O’Reilly, S. Maritorena, D. A. Siegel et al., “Ocean color chlorophyll a algorithms for SeaWiFS, OC2 and OC4: version 4," in SeaWiFS Postlaunch Calibration and Validation Analysis, S. B. Hooker and E. R. Firestone, Eds., Part 3, pp. 9-27, NASA Goddard Space Flight Center, Greenbelt, Md, USA, 2000.

[19] K. L. Carder, F. R. Chen, Z. P. Lee, S. K. Hawes, and D. Kamykowski, "Semianalytic Moderate-Resolution Imaging Spectrometer algorithms for chlorophyll $\alpha$ and absorption with bio-optical domains based on nitrate-depletion temperatures," Journal of Geophysical Research: Oceans, vol. 104, no. 3, Article ID 1998JC900082, pp. 5403-5421, 1999. 
[20] S. Sathyendranath, G. Cota, V. Stuart, H. Maass, and T. Platt, "Remote sensing of phytoplankton pigments: a comparison of empirical and theoretical approaches," International Journal of Remote Sensing, vol. 22, no. 2-3, pp. 249-273, 2001.

[21] D. A. Siegel, S. Maritorena, N. B. Nelson, and M. J. Behrenfeld, "Independence and interdependencies among global ocean color properties: reassessing the bio-optical assumption," Journal of Geophysical Research C: Oceans, vol. 110, no. 7, pp. 1-14, 2005.

[22] Y. B. Son, J. Ishizaka, J.-C. Jeong, H.-C. Kim, and T. Lee, "Cochlodinium polykrikoides red tide detection in the South Sea of Korea using spectral classification of MODIS data," Ocean Science Journal, vol. 46, no. 4, pp. 239-263, 2011.

[23] D. Z. Zhao, F. S. Zhang, L. Zhao, and P. F. Cong, "Detect of chlorophyll a and red tide in coastal water using band ration of AVHRR," Marine Environmental Science, vol. 22, no. 4, pp. 912, 2003.

[24] C. Hu, F. E. Muller-Karger, D. C. Biggs et al., "Comparison of ship and satellite bio-optical measurements on the continental margin of the NE Gulf of Mexico," International Journal of Remote Sensing, vol. 24, no. 13, pp. 2597-2612, 2003.

[25] R. M. Letelier and M. R. Abbott, "An analysis of chlorophyll fluorescence algorithms for the moderate resolution imaging spectrometer (MODIS)," Remote Sensing of Environment, vol. 58, no. 2, pp. 215-223, 1996.

[26] W. E. Esaias, M. R. Abbott, I. Barton et al., "An overview of MODIS capabilities for ocean science observations," IEEE Transactions on Geoscience and Remote Sensing, vol. 36, no. 4, pp. 1250-1265, 1998.

[27] M. Babin, A. Morel, and B. Gentili, "Remote sensing of sea surface sun-induced chlorophyll fluorescence: consequences of natural variations in the optical characteristics of phytoplankton and the quantum yield of chlorophyll a fluorescence," International Journal of Remote Sensing, vol. 17, no. 12, pp. 24172448, 1996.

[28] D. Z. Zhao, F. S. Zhang, F. Du, H. Guo, and L. Zhao, "Fluorenscence peak near $700 \mathrm{~nm}$ on the reflectance spectrum of algae in water: the relationship of fluorenscence line height with chlorophyll a concention," High Technology Letters, vol. 14, no. 5, pp. 68-72, 2004.

[29] H. M. Dierssen, R. M. Kudela, J. P. Ryan, and R. C. Zimmerman, "Red and black tides: quantitative analysis of waterleaving radiance and perceived color for phytoplankton, colored dissolved organic matter, and suspended sediments," Limnology and Oceanography, vol. 51, no. 6, pp. 2646-2659, 2006.

[30] J. P. Cannizzaro, K. L. Carder, F. R. Chen, C. A. Heil, and G. A. Vargo, "A novel technique for detection of the toxic dinoflagellate, Karenia brevis, in the Gulf of Mexico from remotely sensed ocean color data," Continental Shelf Research, vol. 28, no. 1, pp. 137-158, 2008.

[31] H. Sasaki, A. Tanaka, M. Iwataki et al., "Optical properties of the red tide in Isahaya Bay, southwestern Japan: influence of chlorophyll a concentration," Journal of Oceanography, vol. 64, no. 4, pp. 511-523, 2008.

[32] H. R. Gordon, O. B. Brown, R. H. Evans et al., "A semi-analytic model of ocean color," Journal of Geophysical Research, vol. 93, pp. 10909-10924, 1988.

[33] K. L. Carder, S. K. Hawes, R. G. Steward, T. G. Peacock, and C. O. Davis, "Model for the interpretation of hyperspectral remotesensing reflectance," Applied Optics, vol. 33, no. 24, pp. 57215732, 1994.
[34] R. W. Austin, "The remote sensing of spectral radiance from below the ocean surface," in Optical Aspects of Oceanography, N. G. Jerlov and Steemann-Nielsen, Eds., pp. 317-344, Academic Press, London, UK, 1974.

[35] Z. Lee, K. L. Carder, C. D. Mobley, R. G. Steward, and J. S. Patch, "Hyperspectral remote sensing for shallow waters. I. A semianalytical model," Applied Optics, vol. 37, no. 27, pp. 63296338, 1998.

[36] S. A. Garver and D. A. Siegel, "Inherent optical property inversion of ocean color spectra and its biogeochemical interpretation 1. Time series from the Sargasso Sea," Journal of Geophysical Research, vol. 102, no. 8, pp. 18607-18625, 1997.

[37] S. Maritorena, D. A. Siegel, and A. R. Peterson, "Optimization of a semianalytical ocean color model for global-scale applications," Applied Optics, vol. 41, no. 15, pp. 2705-2714, 2002.

[38] S. Maritorena and D. A. Siegel, "Consistent merging of satellite ocean color data sets using a bio-optical model," Remote Sensing of Environment, vol. 94, no. 4, pp. 429-440, 2005.

[39] Z. P. Lee and K. L. Carder, "Effect of spectral band numbers on the retrieval of water column and bottom properties from ocean color data," Applied Optics, vol. 41, no. 12, pp. 2191-2201, 2002.

[40] Z. Lee, K. L. Carder, and K. Du, "Effects of molecular and particle scatterings on the model parameter for remote-sensing reflectance," Applied Optics, vol. 43, no. 25, pp. 4957-4964, 2004.

[41] Z. Lee, R. Arnone, C. Hu, P. J. Werdell, and B. Lubac, "Uncertainties of optical parameters and their propagations in an analytical ocean color inversion algorithm," Applied Optics, vol. 49, no. 3, pp. 369-381, 2010.

[42] P. J. Werdell and C. S. Roesler, "Remote assessment of benthic substrate composition in shallow waters using multispectral reflectance," Limnology and Oceanography, vol. 48, no. 1, pp. 557-567, 2003.

[43] B. A. Franz and P. J. Werdell, "A generalized framework for modeling of inherent optical properties in remote sensing applications," in Proceedings of the Ocean Optics, Anchorage, Alaska, USA, September-October 2010.

[44] C. J. Gobler, D. L. Berry, S. T. Dyhrman et al., "Niche of harmful alga Aureococcus anophagefferens revealed through ecogenomics," Proceedings of the National Academy of Sciences of the United States of America, vol. 108, no. 11, pp. 4352-4357, 2011.

[45] R. D. Vaillancourt, C. W. Brown, R. R. L. Guillard, and W. M. Balch, "Light backscattering properties of marine phytoplankton: relationships to cell size, chemical composition and taxonomy," Journal of Plankton Research, vol. 26, no. 2, pp. 191-212, 2004.

[46] J. L. Mueller and G. S. Fargion, Ocean Optics Protocols for Satellite Ocean Color Validation, NASA Goddard Space Flight Center, Greenbelt, Md, USA, 2002.

[47] C. D. Mobley, "Estimation of the remote-sensing reflectance from above-surface measurements," Applied Optics, vol. 38, no. 36, pp. 7442-7455, 1999.

[48] L. Van Heukelem and C. S. Thomas, "Computer-assisted highperformance liquid chromatography method development with applications to the isolation and analysis of phytoplankton pigments," Journal of Chromatography A, vol. 910, no. 1, pp. 3149, 2001.

[49] L.-L. Jiang, L. Wang, D.-Z. Zhao, and X. Wang, "Backscattering characteristics of Amphidinium carerae Hulburt," Spectroscopy and Spectral Analysis, vol. 33, no. 7, pp. 1892-1896, 2013.

[50] L. L. Jiang, L. Wang, D. Z. Zhao, X. Wang, and X. X. Wang, "Spectral variability of particulate backscattering of nanoplankton and microplankton-focusing on skeletonema costatum 
and prorocentrum micans," Marine Environmental Science, vol. 32, no. 6, pp. 884-888, 2013.

[51] L. L. Jiang, D. Z. Zhao, and L. Wang, "Backscattering properties of marine phytoplankton Prorocentrum micans," International Journal of Remote Sensing, vol. 35, no. 11-12, pp. 4275-4286, 2014.

[52] D. Stramski, A. Bricaud, and A. Morel, "Modeling the inherent optical properties of the ocean based on the detailed composition of the planktonic community," Applied Optics, vol. 40, no. 18, pp. 2929-2945, 2001.

[53] Y.-H. Ahn, A. Bricaud, and A. Morel, "Light backscattering efficiency and related properties of some phytoplankters," Deep Sea Research Part A, Oceanographic Research Papers, vol. 39, no. 11-12, pp. 1835-1855, 1992.

[54] G. Dall'Olmo, T. K. Westberry, M. J. Behrenfeld, E. Boss, and W. H. Slade, "Significant contribution of large particles to optical backscattering in the open ocean," Biogeosciences, vol. 6, no. 6, pp. 947-967, 2009.

[55] A. L. Whitmire, W. Scott Pegau, L. Karp-Boss, E. Boss, and T. J. Cowles, "Spectral backscattering properties of marine phytoplankton cultures," Optics Express, vol. 18, no. 14, pp. 1507315093, 2010.

[56] W. Zhou, G. F. Wang, Z. H. Sun et al., "Variations in the optical scattering properties of phytoplankton cultures," Optics Express, vol. 20, no. 10, pp. 11189-11206, 2012.

[57] A. Morel and Y. H. Ahn, "Optics of heterotrophic nanoflagellates and ciliates: a tentative assessment of their scattering role in oceanic waters compared to those of bacterial and algal cells," Journal of Marine Research, vol. 49, no. 1, pp. 177-202, 1991. 

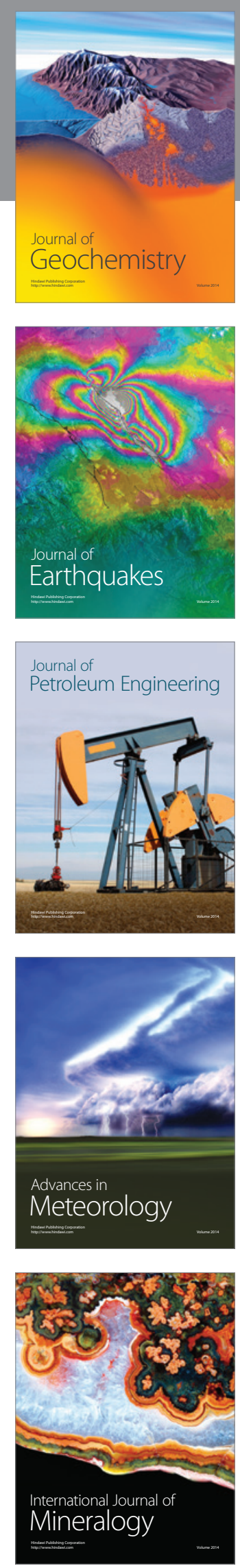
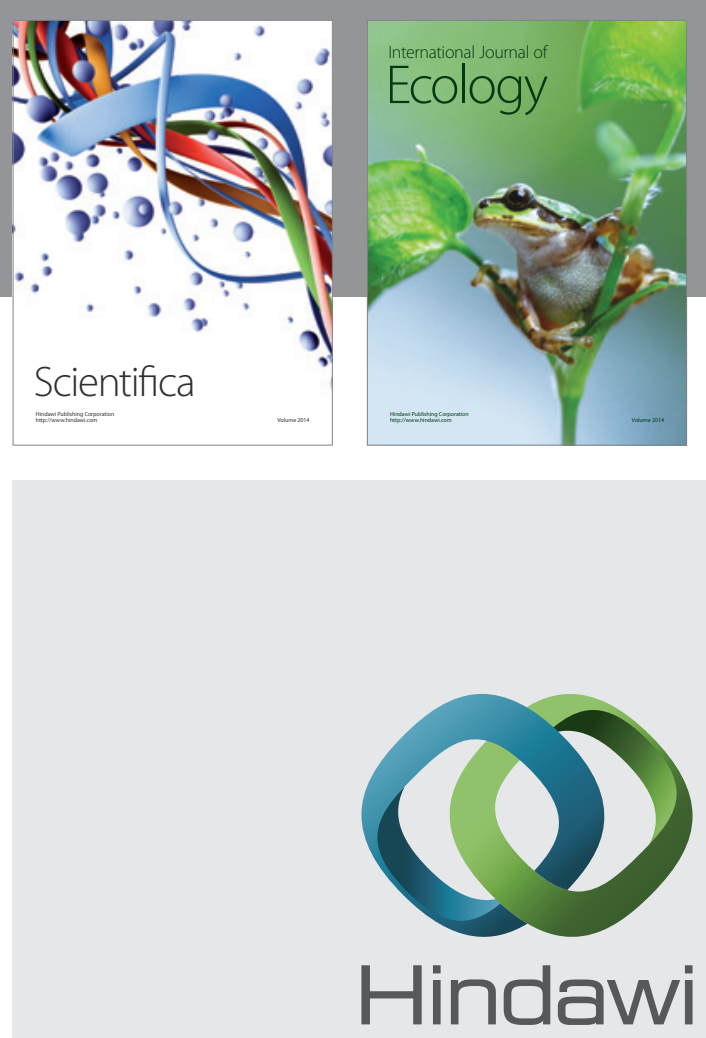

Submit your manuscripts at

http://www.hindawi.com
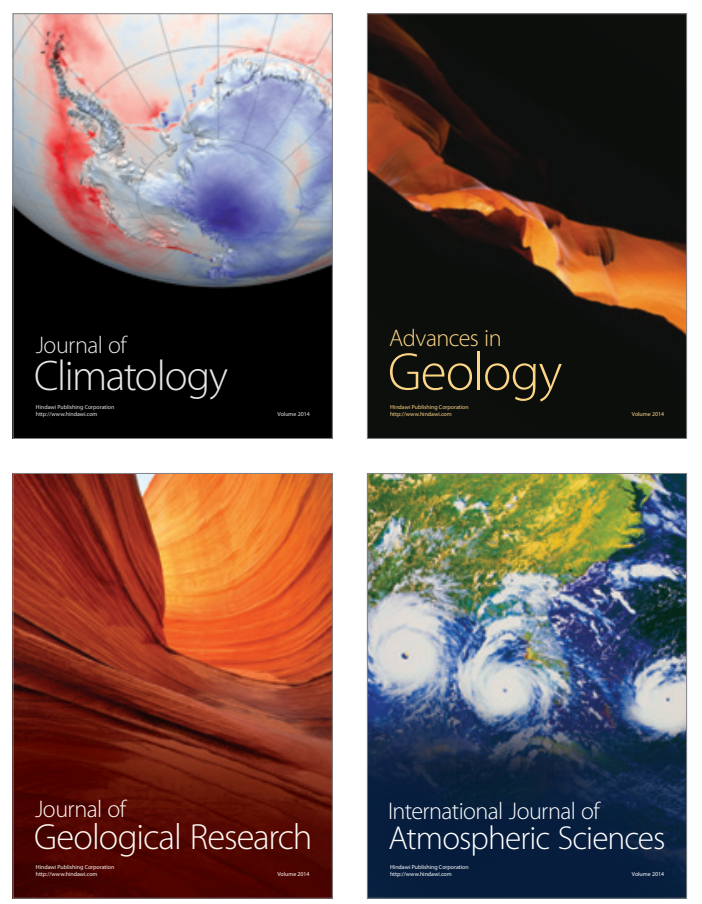

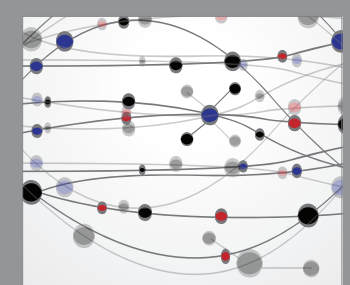

The Scientific

\section{World Journal}
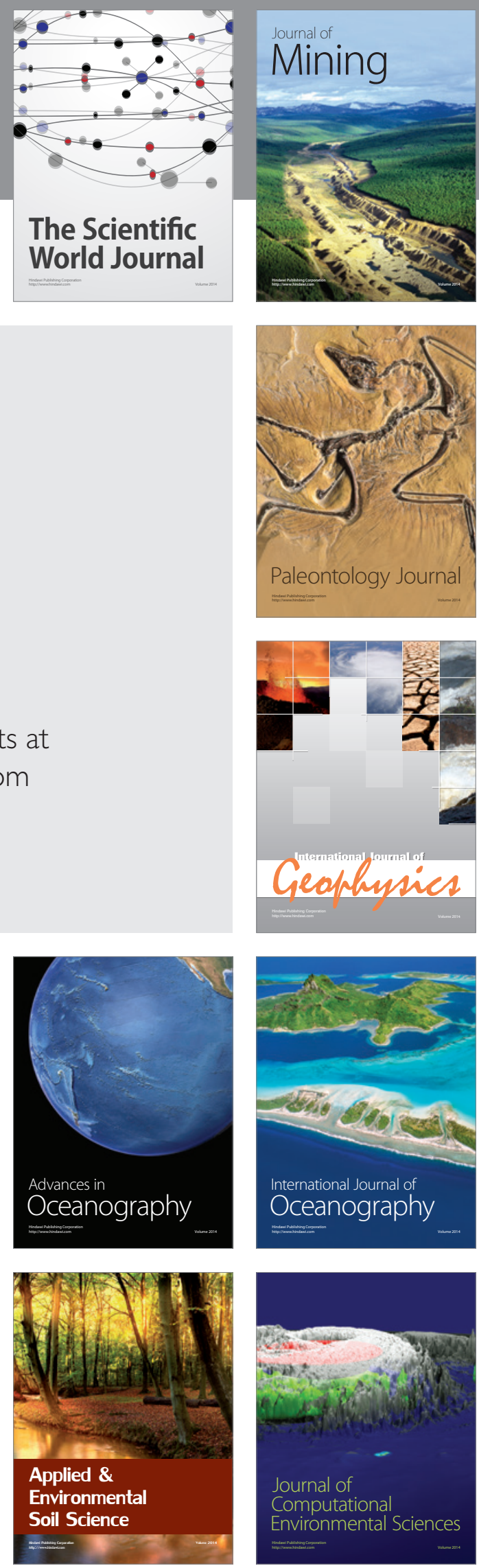